\title{
The Effect of Consumer Experience on Food Delivery Apps
}

Nina Farisha Isa, Norhayati Mat Yusoff@Mohd Yusof, Irina Mohd Akhir, Suriati Osman

To Link this Article: http://dx.doi.org/10.6007/IJARBSS/v11-i13/8549

DOI:10.6007/IJARBSS/v11-i13/8549

Received: 11 December 2020, Revised: 02 January 2021, Accepted: 17 January 2021

Published Online: 29 January 2021

In-Text Citation: (Isa et al., 2021)

To Cite this Article: Isa, N. F., Yusof, N. M. Y., Akhir, I. M., \& Osman, S. (2021). The Effect of Consumer Experience on Food Delivery Apps. International Journal of Academic Research in Business and Social Sciences, 10(17), 299-309.

\section{Copyright: (c) 2021 The Author(s)}

Published by Human Resource Management Academic Research Society (www.hrmars.com)

This article is published under the Creative Commons Attribution (CC BY 4.0) license. Anyone may reproduce, distribute, translate and create derivative works of this article (for both commercial and non-commercial purposes), subject to full attribution to the original publication and authors. The full terms of this license may be seen at: http://creativecommons.org/licences/by/4.0/legalcode

Special Issue: Beyond 2021 and COVID-19 - New Perspective in the Hospitality \& Tourism Industry, 2021, Pg. 299 - 309

Full Terms \& Conditions of access and use can be found at http://hrmars.com/index.php/pages/detail/publication-ethics 


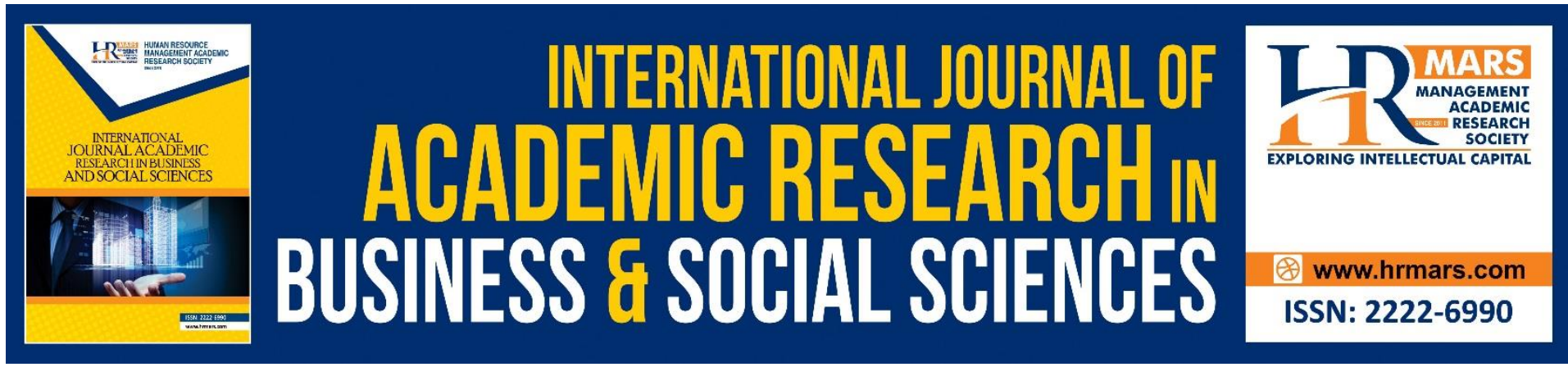

\title{
The Effect of Consumer Experience on Food Delivery Apps
}

\author{
Nina Farisha Isa' ${ }^{1}$, Norhayati Mat Yusoff@Mohd Yusof ${ }^{1}$, Irina Mohd \\ Akhir $^{2}$, Suriati Osman ${ }^{1}$ \\ ${ }^{1}$ Faculty of Hotel and Tourism Management, Universiti Teknologi MARA, Selangor, ${ }^{2}$ Faculty \\ of Hotel and Tourism Management, Universiti Teknologi MARA, Pulau Pinang
}

\begin{abstract}
We examined the relationships between the determinants that affect consumer's use of food delivery apps. Using an extended flow theory model, we explored consumers' experiences in purchasing delivery food through mobile apps. We distributed a self-administered questionnaire online and used structural equation modeling to test the hypotheses. We found that consumer experience (web and digital) had a significant effect on buying intention behavior. The empirical findings show that consumers' experience has significant effect on buying behavior when using the application. Consumer experience in term of the usability, interactivity and aesthetic of the web positively affects food delivery apps buying intention behavior. Further, this study finds that consumers had experience buying from the website are based on the functionality rather than psychology and content factors. Furthermore, digital experience demonstrates a stronger effect on buying behavior with more experience using the food delivery application. This study is one of the early studies to investigate the role of consumer experience. In addition, we find that in user's first interaction with food delivery apps, web experience (usability, interactivity, aesthetic) and digital experience has a larger impact on their buying intention behavior.
\end{abstract}

Keywords: Consumer Experience, Web Experience, Digital Experience, Usability, Interactivity, Aesthetic, Buying Intention Behavior.

\section{Introduction}

As food service industry customers are notoriously fickle, the industry has to keep up with changes in taste, fashion, and ease of access. Technology assists in this process, and with the dramatic growth of wireless communication technology and the high penetration rate of the Internet, food service businesses now rely on technology as a major information resource and marketing tool (Bickerton, 2015). The proliferation of smartphones has exacerbated this trend, as they provide for the real-time connectivity of mobile apps, making food delivery apps popular with busy diners in pursuit of speed and convenience. As food delivery apps have increased in popularity, the online food delivery service market is expected to grow 17.9 percent annually to reach revenue of US\$370 million. Expected in four years the competitive 
dynamics of the food delivery market will be increased particularly in Malaysia (https://www.theedgemarkets.com/article,2020).

Retail food delivery is a courier service in which a restaurant, store, or independent food delivery company delivery food to a customer. An order is typically made either through a restaurant or grocer's website or phone, or through a food ordering company. The delivered items can include entrees, sides, drinks, desserts, or grocery items and are typically delivered in boxes or bags. The delivery person will normally drive a car, but in bigger cities where homes and restaurants are closer together, they may use bikes or motorized scooters. Consumers and business around the globe have been more connected than ever before with the presence of Internet. Customer can, depending on the delivery company, choose to pay online or in person, with cash or card. A flat rate delivery fee is often charged with what the customer has bought. Tips are often customary for food delivery service.

With accelerated competition in the food service industry and the popularity of food delivery apps, it is useful to have an understanding of the factors that entice consumers to use these apps. Therefore, we used the extended web experience theory to investigate the determinants that either drive or impede user intention to use food delivery apps. It is indicated in this model that system use will be based on web and digital experience. Therefore, customer experience has always been at the focal point of the entertainment business and widely in the services sector (Otto \& Ritchie, 1996). Thus, this study demonstrates that consumer with higher knowledge in technology may emphasize different perceived of consumer experience (Constantinides \& Geurts, 2005). In summary, we expect that this study can contribute to the existing literature by connecting the studies of consumer experience and buying intention behaviour. The remainder of this study is structured as follows. In Section 2, we present the theoretical background. Then we develop our research hypotheses followed by conducting an online survey and analyzing the data. Finally, we summarize our findings and discuss the implications and limitations of this study.

\section{Consumer Experience}

Consumer experience has been a popular topic among academic researchers as well as industry professionals. The Marketing Science Institute made it a research priority in 2010 , and since then, there have been numerous scientific studies of consumer experience. While there has been an increase in the exploration of consumer experience since its introduction in Holbrook and Hirschmann's (1982) seminal article, however Ali et al. (2016) mention that its conceptualization still lacks of clarity. Based on Holbrook and Hirschman's research on emotional aspects of experience's is significance in the 1980s, Pine and Gilmore (1998) proposes the idea of consumer experience as customer look for experiences that allow them to spend time enjoying a series of memorable events that a company stages is to engage them in an inherently personal way. A large number of scholars has described experiences as interactions with multiple actors such as the company or its elements (employees, physical environment and other customers) Berry et al. (2002); Meyer and Schwager (2007), while others consider service experience a response (sensory, affective, intellectual and behavioral) to interactions with service related stimuli. 
However, understanding the mechanisms of buying behavior and the behavior of the online consumer experience is a priority issue for practitioners to compete in the fast expanding online marketplace. This topic is also increasingly drawing the attention of researchers. Indicative of this is the fact that traditional marketing in the past most of the research and debate is focused on the identification and analysis of factors that one way or another can influence the online consumer's behavior and decision-making process (Liu \& Arnett, 2000; O'Cass \& Fenech, 2003). One of the determinants that have been the interest of many IS and marketing researchers are influence of web experience on online buying decision. Constantinides and Geurts (2005) extend the concept of flow by formulating a set of variable known as Web experience. They refer to Web experience as the retailers' online business by online consumer on the design and other marketing elements of the online presentation to represent the general consumer experience in interacting on online environments. As a result, they identify different elements of flow that represent the Web experience variable that have an impact on online purchasing behavior. Web experience variables are controllable marketing tools that influence or shape the online consumer behavior during online interaction (Constantinides \& Geurts, 2005). Since Web experience is complex and intangible, its essence is quantified by multi dimensional factors, such as functionality, psychological and content factors to examine their relationship with online purchase behavior. However, Constantinides (2004) describes web experience as the consumer's total impression about the online company not only addressing the consumer's product needs and expectations but also assisting the consumers through the steps of the buying process which likely to influence the buying decision of the online consumer. This research supported by Constantinides (2002) that propose web experience as the consumer's whole perception about the online company. Constantinides (2004) suggests that web experience is consists of five elements such as usability, interactivity, aesthetics, trust, and marketing mix. Prior studies of web experience are developed by using flow theory (Constantinides, 2004).

Therefore, with Web experience drives the consumer to buy online and interact between consumer and consumer on sharing their experience of buying the product. For instance, consumer able to search the visual search, customer review, selection of product and different range of price through the online website. Constantinides (2008) also concur the effect of Web 2.0 on consumer decision-making process is becoming increasing due to the advantages of Web 2.0 to the users such as transparency, referrals, contact with other users and effect on customer power (Urban, 2003). Prior literature denotes that in web experience, hedonic element are related to experiential stimuli that motivates consumers to participate more and seek benefits to allocate their leisure time in the web experience activities (Ha \& Stoel, 2012; Wang \& Fesenmaier, 2004).

The findings of Constantinides (2003) comprehensive literature review are summarized in a model depicting the main categories of factors affecting the online consumer. The study identifies three groups of web experience - functional factor, psychological factor and content factor. This classification underlines the fact that most researchers endorse the suggestion that like in online markets, the interaction of functional, psychology and content factor underpins also the online decision making process (O'Cass \& French, 2003). Although these prior studies have shed light on the importance of consumer experience, some issues remain unresolved. First, there is a lack of generally accepted principles for designing food delivery apps. In order to derive these principles, it is necessary to identify the design elements that 
are essential to the food delivery apps. With respect to this, prior literature tends to view web experience as a functional, psychological and content factors on website, but they have failed to design elements are essential to website as well as mobile apps. Therefore, this study intends to identify an antecedents that is essential to website and mobile apps by investigating what is the role of web and digital experience when people use the food delivery apps.

\section{Purchase Intention}

Prior studies found that purchase intention is the likelihood that a customer will buy a particular product/service (Dodds, Monroe \& Grewal, 1991). Intention to purchase from food delivery apps is the main dependent variable of the model, derived from the TRA, that posits that behavioural intentions rather than attitudes are the main vital predictor of actual buying behavior and this relationship has been empirically examined in hospitality and tourism industry (Fishbein \& Ajzen, 1975; Sparks \& Browning, 2011; Amaro \& Duarte, 2015). It is assumed that intentions capture the motivational factors that influence behavior and the stronger the intention to engage in behavior, the more likely should be its performance (Ajzen, 1991). Behavioural intentions have been well established as a strong predictor of actual usage of information technologies (Davis, Bagozzi \& Warshaw, 1989; Venkatesh, Morris, Davis \& Davis, 2003) and of online shopping (Ajzen, 2011; Lin, 2007; Pavlou \& Fygenson, 2006). Furthermore, in voluntary settings, as in the case of online travel shopping and online hotel booking, intention to behave has been postulated as the best predictor of behavior (Moital, Vaughan \& Edwards, 2009). Previous research has shown that consumer experience are driving forces of online purchase intentions (Constantinides, 2011; Ali, 2016).

\section{Methodology}

This study chose Grab Food as the popular food delivery apps in Malaysia. This study uses data collected from online survey and offline survey conducted among postgraduate student at public universities. Using students as a research sample in common in social sciences given the experience of today students as internet users and typical young virtual consumers. Evidently, Zhang and Prybutok (2005) argue that student segments possess high purchasing power, receptive to new products, trend setters likely to influence major household purchases, thus have great potential to become lifetime consumers. Besides, students are also familiar with online shopping environment hence providing a strong basis for pragmatic understanding of online consumer behavior. This study adopts a convenience sampling, a type of non-probability sampling technique because its procedure that allows selection of the subjects who are most conveniently available.

The measurement items for the web experiences factors are adapted from previous studies where their psychometric properties have been established (Koufaris, 2002; Constantinides \& Geurts, 2005; Lim et al., 2006). All constructs are measured using six point Likert scale representing (1) strongly disagree and (6) strongly agree. This study uses a dichotomous scale to measure online purchasing behavior as it focuses on the decision whether to perform or not to perform online purchasing. Given this concern, Gupta (2019) also studied consumer's online buying on food delivery application (app).

Table 1 presents the demographic details of online consumers participate in this study. Summary of the demographic data reveals that the number of female online consumers is 
more than male consumers with 69.8 were female and the remaining 30.2 of the online consumers were male. All respondents were 18 years of age and above, 65.6 per cent of the respondents were under the age of 18-25years. Education level of the respondents, 70.6 percent had an education level of university or above. More specifically their marital status is 73.9 percent is still single. Furthermore, 44.3 percent of the online consumer buying according to daily basis when using the food delivery apps. All 969 respondents were active with Grab Food, with average 97.2 percent of the respondent had registered with Grab Food.

Table 1: Characteristics of the sample of respondents

\begin{tabular}{|c|c|c|}
\hline Demographic Variables & $\begin{array}{l}\text { Number of online } \\
\text { consumers }\end{array}$ & Percent (\%) \\
\hline \multicolumn{3}{|l|}{ Age } \\
\hline $18-25$ & 638 & 65.6 \\
\hline $26-34$ & 256 & 26.3 \\
\hline $35-43$ & 79 & 8.1 \\
\hline \multicolumn{3}{|l|}{ Gender } \\
\hline Male & 294 & 30.2 \\
\hline Female & 679 & 69.8 \\
\hline \multicolumn{3}{|l|}{ Education } \\
\hline Primary & 0 & 0 \\
\hline Secondary & 7 & 0.7 \\
\hline Certificate & 6 & 0.6 \\
\hline Diploma & 24 & 2.5 \\
\hline Degree & 687 & 70.6 \\
\hline Master Degree & 214 & 22.0 \\
\hline Doctorate & 35 & 3.6 \\
\hline \multicolumn{3}{|l|}{ Marital status } \\
\hline Married & 245 & 25.2 \\
\hline Single & 719 & 73.9 \\
\hline Single Parent & 9 & 0.9 \\
\hline \multicolumn{3}{|l|}{ Frequency buying online } \\
\hline Daily basis & 431 & 44.3 \\
\hline 2-3 times a week & 259 & 26.6 \\
\hline 4-5 times a week & 158 & 16.2 \\
\hline Once a month & 125 & 12.8 \\
\hline \multicolumn{3}{|l|}{ Payment } \\
\hline Credit Card & 626 & 64.3 \\
\hline PayPal & 30 & 3.1 \\
\hline Bitcoin & 0 & 0 \\
\hline Cheque & 0 & 0 \\
\hline Online Transfer & 317 & 32.6 \\
\hline Cash & 0 & 0 \\
\hline \multicolumn{3}{|l|}{ Grab Food App account } \\
\hline Yes & 946 & 97.2 \\
\hline No & 27 & 2.8 \\
\hline
\end{tabular}




\section{Result and Analysis}

The research model of this study was tested using Partial Least Squares (PLS) with PLS Graph 3.0. PLS is a component based structural equation modelling technique, which facilitates simultaneous tests of measurement models and structural models and is particularly suitable for theory development and theory testing (Hair et al., 2016; Barclay, Thompson \& Higgins, 1995). Measurement model: Assessments of measurement models should examine (1) individual item reliability, (2) internal consistency, and (3) discriminant validity (Hair et al., 2016; Barclay et al., 1995). A general method for checking individual item reliability involves checking whether individual loadings are above 0.6 or ideally 0.7 (Hair et al., 2016). All items in the present study model load heavily on their respective constructs, with loadings above 0.7 , thus demonstrating adequate individual item reliability. All items loadings and cross loadings and construct reliability coefficients are shown in Table 2. Since all reliability scores are above 0.6 and above, the internal consistency criteria are met.

The third step in assessing the measurement model involves examining its discriminant validity. Off diagonal elements in Table 3 represent correlations of all latent variables while the diagonal elements are the square roots of the average variances extracted (AVE) of the latent variables. For adequate discriminant validity, the square roots of AVE of any latent variable should be greater than the correlations between the latent variable and other latent variables (Hair et al., 2016; Barclay et al., 1995). This means that the diagonal elements should be greater than corresponding off diagonal ones. Data shown in Table 3 satisfy this requirement. Another criterion for adequate discriminant validity requires that the loadings of indicators on their respective latent variables be greater than the loadings of other indicators on these latent variables and those of these indicators on other latent variables. The loadings and cross loadings for this study demonstrate adequate discriminant validity.

Structural model: The standardized PLS path coefficients for testing the structural model are shown in Table 5. Overall, PLS analyses generally confirm that the consumer experience of all four design elements (i.e. usability, interactivity and aesthetic) and digital experience significantly influences consumer buying intention behavior. Therefore, $\mathrm{H} 1 \mathrm{a}-\mathrm{C}$ and $\mathrm{H} 2$ are all supported.

Table 2: Measurement Model Convergent Validity

\begin{tabular}{cccccc}
\hline Construct & Item & Loadings & AVE & CR & $\begin{array}{c}\text { Cronbach's } \\
\text { Alpha }\end{array}$ \\
\hline Usability & Usa1 & 0.865 & 0.726 & 0.941 & 0.925 \\
& Usa2 & 0.857 & & & \\
& Usa3 & 0.847 & & & \\
& Usa4 & 0.881 & & \\
& Usa5 & 0.845 & & & \\
& Usa6 & 0.817 & & 0.906 \\
\hline Interactivity & Int1 & 0.825 & 0.681 & & \\
& Int2 & 0.839 & & & \\
& Int3 & 0.867 & & & \\
& Int4 & 0.783 & & & \\
& & 0.838 & & & \\
\hline
\end{tabular}




\begin{tabular}{|c|c|c|c|c|c|c|c|c|c|}
\hline & $\begin{array}{l}\text { Int5 } \\
\text { Int6 }\end{array}$ & & 0.794 & & & & & & \\
\hline \multirow[t]{6}{*}{ Aesthetic } & Aes1 & & 0.828 & \multirow{6}{*}{\multicolumn{2}{|c|}{0.644}} & \multirow{6}{*}{\multicolumn{2}{|c|}{0.915}} & \multirow{6}{*}{\multicolumn{2}{|c|}{0.889}} \\
\hline & Aes2 & & 0.841 & & & & & & \\
\hline & Aes3 & & 0.843 & & & & & & \\
\hline & Aes4 & & 0.754 & & & & & & \\
\hline & Aes5 & & 0.814 & & & & & & \\
\hline & Aes6 & & 0.726 & & & & & & \\
\hline Digital & De1 & & 0.857 & \multirow{6}{*}{\multicolumn{2}{|c|}{0.787}} & \multicolumn{2}{|r|}{0.957} & \multicolumn{2}{|r|}{0.946} \\
\hline \multirow[t]{5}{*}{ Experience } & De2 & & 0.920 & & & & & & \\
\hline & De3 & & 0.916 & & & & & & \\
\hline & De4 & & 0.894 & & & & & & \\
\hline & De5 & & 0.849 & & & & & & \\
\hline & De6 & & 0.884 & & & & & & \\
\hline Buying & $\mathrm{BI} 1$ & & 0.862 & \multicolumn{2}{|r|}{0.760} & \multicolumn{2}{|r|}{0.950} & \multicolumn{2}{|r|}{0.937} \\
\hline \multirow[t]{5}{*}{ Intention } & $\mathrm{B} 12$ & & 0.869 & & & & & & \\
\hline & $\mathrm{BI} 3$ & & 0.860 & & & & & & \\
\hline & B14 & & 0.904 & & & & & & \\
\hline & $\mathrm{BI} 5$ & & 0.876 & & & & & & \\
\hline & $\mathrm{BI} 6$ & & 0.859 & & & & & & \\
\hline Variables & $\begin{array}{l}\text { Cronbach } \\
\text { Alpha }\end{array}$ & AVE & CR & AES & BI & $\mathrm{DE}$ & INT & USA & WE \\
\hline Aesthetic (AES) & 0.889 & 0.644 & 0.915 & 0.802 & & & & & \\
\hline $\begin{array}{l}\text { Buying } \\
\text { Intention (BI) }\end{array}$ & 0.937 & 0.760 & 0.950 & 0.549 & 0.872 & & & & \\
\hline $\begin{array}{l}\text { Digital } \\
\text { experience } \\
\text { (DE) }\end{array}$ & 0.946 & 0.787 & 0.957 & 0.609 & 0.600 & 0.887 & & & \\
\hline $\begin{array}{l}\text { Interactivity } \\
\text { (INT) }\end{array}$ & 0.906 & 0.680 & 0.927 & 0.626 & 0.482 & 0.681 & 0.825 & & \\
\hline Usability (USA) & 0.925 & 0.726 & 0.941 & 0.493 & 0.461 & 0.611 & 0.729 & 0.852 & \\
\hline $\begin{array}{l}\text { Web } \\
\text { experience } \\
\text { (WE) }\end{array}$ & 1.000 & 1.000 & 1.000 & 0.603 & 0.592 & 0.994 & 0.672 & 0.594 & 1.000 \\
\hline
\end{tabular}


Table 4: Structural Model of First Order Research Model

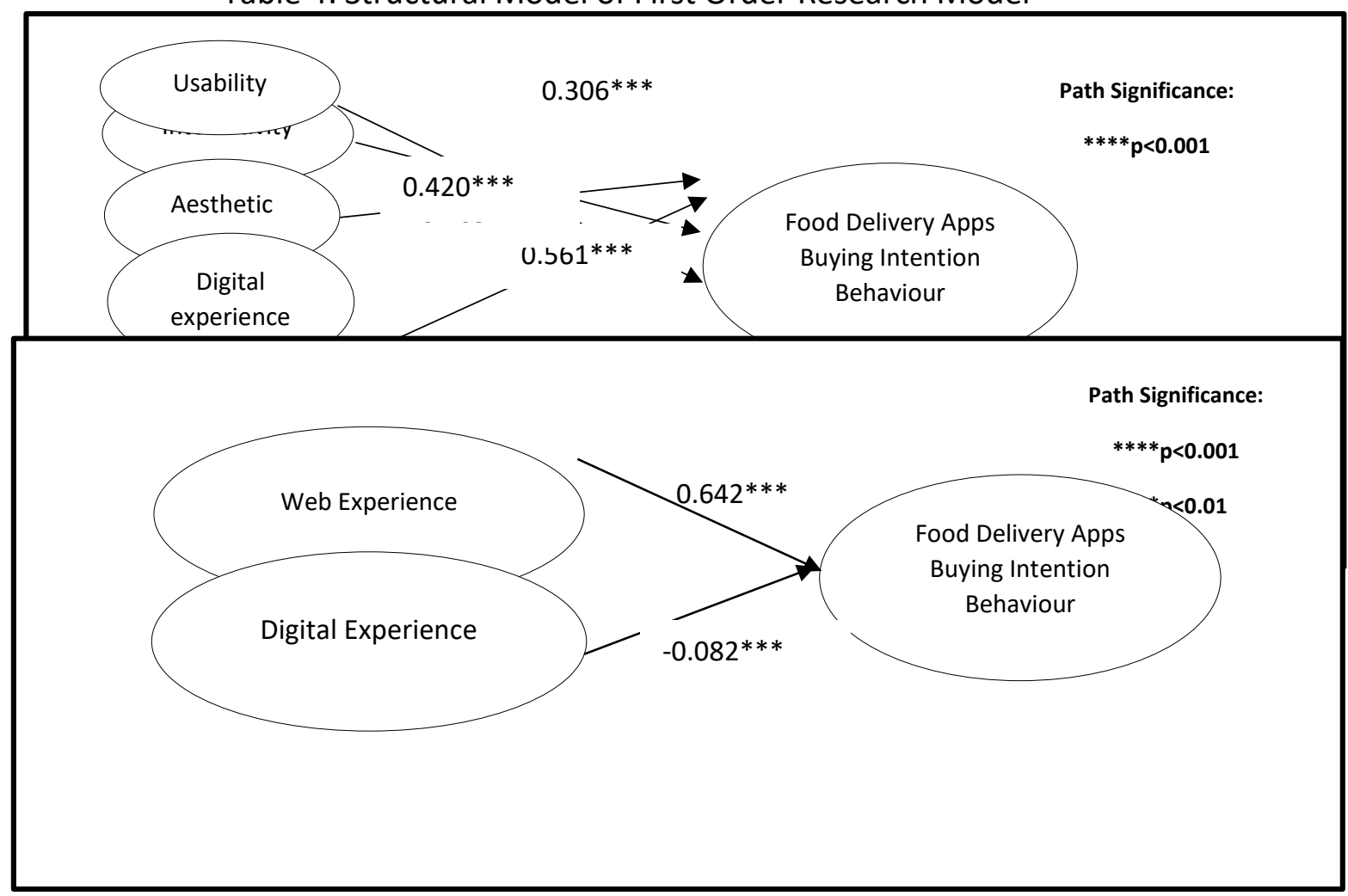

\section{Conclusion}

In this study, we explored how consumers' evaluate and perceived the role of consumer experience (web and digital) by using food delivery apps to make buying decision behavior. The results show that web and digital experience positively affect consumers' buying behavior, which further increases buying intention. In addition, we find significant and interesting consumer differences, depending on their levels of web experiences. More specifically, consumers with high usability level experience indicate that stronger the effect of consumer buying intention by using the food delivery apps. Thus, the results also show that the consumer experience with high level of interactivity will gives more significant towards buying intention when using the food delivery apps. Aesthetic elements showed that the higher consumer experience aesthetic, the higher buying intention. Hence, we conclude that the relationship between web experience and digital experience is fully affected by consumer experience toward food delivery apps buying intention behavior. Researchers has likewise posited that the web experience manifests via functional, psychological and content elements may affect consumer buying intention behavior. Consistent with these contentions, our findings have clearly revealed the significance of consumer experience. First, the results show that web experience does have a positive effect on their perception of the website usability. This finding is consistent with prior studies and lends substantial support to the spillover effects, suggesting that inherently different system aspects could be associated perceptually.

\section{Acknowledgment}

The authors are grateful to the referees for their suggestions and comments that improve the quality of this paper. 


\section{Corresponding Author}

Nina Farisha Isa. Universiti Teknologi MARA, Selangor.

E-mail: ninafarisha@uitm.edu.my

\section{References}

Ali, F. (2016). Hotel website quality, perceived flow, customer satisfaction and purchase intention. Journal of Hospitality and Tourism Technology, 7(2), 213-228. https://doi.org/10.1108/JHTT-02-2016-0010

Barclay, D., Thompson, R., \& Higgins, C. (1995). The partial least squares (PLS) approach to causal modeling: Personal computer adoption and use as an illustration. Technology Studies, 2(2), 285-309.

Bilgihan, A., Kandampully, J., \& Zhang, T. (2016). Towards a unified customer experience in online shopping environments Antecedents and outcomes. International Journal of Quality and Service Sciences. 8(1), 102-119. https://doi.org/10.1108/IJQSS-07-20150054

Bilgihan, A., Nusair, K., Okumus, F., \& Bujisic, M. (2013). Online experiences: flow theory, measuring Online customer experience in e-commerce and managerial implications for the lodging industry. Journal Information Technology \& Tourism, 14(1), 49-71. https://doi.org/10.1007/s40558-013-0003-3

Borowski, C. (2015). What a great digital customer experience actually looks like. Harvard Business Review. https://hbr.org/2015/11/what-a-great-digital-customer-experienceactually-looks-like

Bronner, F., \& de Hoog, R. (2014). Social media and consumer choice. International Journal of Market Research, 56(1), 51-71. https://doi.org/10.2501/IJMR-2013-053

Chen, C. S., Yen, C. D., \& Hwang, I. M. (2012). Factors influencing the continuance intention to the usage of Web 2.0: An empirical study. Computers in Human Behavior, 28,(3), 933941. https://doi.org/10.1016/j.chb.2011.12.014

Chen, H. (2006). Flow on the net detecting Web user's positive affects and their flow states. Computers in Human Behavior, 22,(2), 221-233. https://doi.org/10.1016/j.chb.2004.07.001

Chen, H., Wigand, R. T., \& Nilan, M.S. (1999). Optimal experience of Web Activities. Computers in Human Behavior, 15(5), 585-608.

Constantinides, E. (2004). Influencing the online consumer's behavior: The web experiences. Internet Research, 14 (2), 111-126. https://doi.org/10.1108/10662240410530835

Constantinides, E., \& Fountain, J. S. (2008). Web 2.0: Conceptual foundations and marketing issues. Journal of Direct Data and Digital Marketing Practice, 9(3), 231-244. https://doi.org/10.1057/palgrave.dddmp.4350098

Constantinides, E., \& Geurts, P. (2005). The impact of web experience on virtual buying behavior: an empirical study. Journal of Customer Behavior, 4(3), 307-336. https://doi.org/10.1362/147539205775181249

Constantinides, E., Romero, C. L., \& Boria, M. A. (2009). Social media: A new frontier for retailers?. European Retail Research, 22, 1-28.

Chung, H., \& Park, Y. G. K. (2003). Identifying key factors affecting consumer purchase behaviour in an online shopping context. International Journal of Retail \& Distribution Management, 31(1), 16-29. https://doi.org/10.1108/09590550310457818 
Csikszentmihalyi, M. (1997). Finding Flow: The Psychology of Engagement with Everyday Life. New York: Basic Books.

Cyr, D. (2014). Return visits: A review of how Web site designs can Engender Visitor Loyalty. Journal of Information Technology, 29(1), 1-26. https://doi.org/10.1057/jit.2013.25

Dailey, L. (2004). Navigational web atmospherics: explaining the influence of restrictive navigation cues. Journal of Business Research, 57(7), 795-803. https://doi.org/10.1016/S0148-2963(02)00364-8

Darley, W. K., Blankson, C., \& Luethge, D. (2010). Toward an integrated framework for online consumer behavior and decision-making process: A review. Journal of Psychology \& Marketing, 27(2), 94-116. https://doi.org/10.1002/mar.20322

Davis, F. D. (1989). Perceived usefulness, perceived ease of use and user acceptance of information technology. MIS Quarterly, 13(3), 318-340. https://doi.org/10.2307/249008

Deng, L., \& Poole, M. S. (2012). Aesthetic design of E-commerce web pages - webpage complexity, order and preference. Electronic Commerce Research and Applications, 11(4), 420-440. https://doi.org/10.1016/j.elerap.2012.06.004

Fiore, A. M., Kim, J., \& Lee, H. H. (2005). Effect of image interactivity technology on consumer responses toward the online retailer. Journal of Interactive Marketing, 19(3), 38-53. https://doi.org/10.1002/dir.20042

Gopalani, A., \& Shick, K. (2011). The service enabled customer experience: A jump start to competitive advantage. Journal of Business Strategy, 32(3), 4-12. https://doi.org/10.1108/02756661111121947

Green, T. D., \& Pearson, M. J. (2009). The examination of two web site usability instruments for use in B2C E-Commerce organizations. Journal of Computer Information Systems, 49(4), 19-32. 